\title{
Avatares da Peça Bem-feita na Dramaturgia Brasileira Contemporânea
}

\author{
Stephan Arnulf Baumgärtel \\ Universidade Estadual de Santa Catarina/UDESC, Florianópolis, Brasil \\ E-mail: stephao08@yahoo.com.br \\ Elen de Medeiros \\ Universidade Federal de Minas Gerais/UFMG, Belo Horizonte, Brasil \\ E-mail: elendemedeiros@hotmail.com \\ João Sanches \\ Universidade Federal da Bahia/UFBA, Salvador, Brasil \\ E-mail: sanchesjoao@ig.com.br
}

A partir do estudo de três autores teatrais contemporâneos, Vinícius Calderoni, Jô Bilac e João Sanches, visamos reconhecer na produção brasileira atual novos avatares da peça bem-feita. Para tanto, partimos antes de um reconhecimento do padrão formal e ideológico desse tipo de peça no século XIX para estabelecer aproximações com os textos do teatro brasileiro do século XXI.

\section{Palavras-chave}

Teatro Brasileiro Contemporâneo. Dramaturgia Brasileira. Peça Bem-feita.
By analysing the work of three contemporary Brazilian playwrights, Vinícius Calderoni, Jô Bilac and João Sanches, we set out to recognize in contemporary Brazilian playwriting new avatars of the well-made play. To do so, we start by describing the formal and ideological pattern inscribed in this kind of playwriting in the 19th century, in order to establish a comparison with some texts of Brazilian dramaturgy in the 21st century. Keywords

Contemporary Brazilian Theatre. Brazilian Dramaturgy. Well-made Play. 
Introdução

\section{Em 2013, a revista Le Monde Diplomatique} Brasil publicou um artigo do diretor alemão Thomas Ostermeier, no qual ele constata uma crise de conteúdo e da forma cênica no teatro contemporâneo ${ }^{1}$. Diz ele:

as formas inovadoras que surgiram nos anos 1970 e 1980 continuam a orientar o credo estético de um grande número de teatros públicos e festivais, ainda que nesse assunto os imitadores estejam longe de se igualar a seus modelos [...] A poetologia desse teatro baseia-se na ideia de que a ação dramática não é mais de nossa época; que o homem não poderia se compreender como mestre de suas ações; que existem tantas verdades subjetivas quanto o número de espectadores presentes; que os acontecimentos representados no palco não exprimem nenhuma verdade válida para todos; que nossa experiência fragmentada do mundo somente encontra sua tradução num teatro fracionado, em que os gêneros se justaponham: corpo, dança, fotos, vídeos, música, palavra... Essa imbricação sensorial assegura ao espectador que este mundo caótico permanecerá para sempre indecifrável e que não há espaço para procurar ligações de causalidade ou culpados.

E conclui que

esse 'realismo capitalista' estetiza uma ideologia vitoriosa [...]. Em um mundo dominado pela doutrina neoliberal, nada poderia dar mais prazer a seus beneficiários que estes pressupostos: ninguém é responsável por nada, e a complexidade do mundo torna ilusória toda tentativa de circunscrever seus mecanismos.

Podemos dizer, com isso, que o realismo hegemônico da contemporaneidade faz uso

1 Ver https://diplomatique.org.br/para-que-serve-o-teatro/, sem páginas. Último acesso: 30 de novembro de 2018. inofensivo, acrítico e divertido de uma forma que foi originalmente pensada para apresentar uma imagem problemática do status quo de sua época, o capitalismo moderno.

Não é a primeira vez que uma forma, originalmente alinhada a uma classe social progressista, vira chavão de diversão e veículo ideológico do conservadorismo bem-humorado dessa mesma classe num momento histórico posterior. Exatamente isso aconteceu com o drama burguês quando caiu nas mãos de autores que cunharam a fórmula da peça bem-feita, assentada temática e formalmente nesse drama realista moderno. Esses autores, como Scribe, ou Sardou, mas até certo ponto também Labiche e Feydeau com seu convite a uma risada pouco comprometida com a dinâmica social, já não representaram uma burguesia que lutou para uma transformação social (ou contra restrições sociais da própria vida afetiva), mas - na abdicação desse objetivo, a partir do momento em que ela tornara-se classe dominante - dedicou-se, em composições formalmente estereotipadas, predominantemente a uma análise moralista de sua estrutura psicossocial.

Como então se articulam as proposições e limitações na parcela da dramaturgia contemporânea que denominamos peça bem-feita? Com quais recursos formais e temáticos ela pode trabalhar (e talvez até possamos afirmar que prefere trabalhar com eles)? Para responder a essas perguntas, vamos primeiro apresentar uma breve leitura crítica das descrições e definições da peça bem-feita tradicional, a fim de criar um suporte analítico que possa ser articulado a textos da dramaturgia brasileira contemporânea. Textos que, devido às funções de suas formas em relação ao conteúdo social inscrito neles, podem ser qualificados 
como exemplos de uma peça bem-feita brasileira atual.

A peça bem-feita: uma dramaturgia posta a serviço de uma função emocional harmonizante

\author{
O termo "peça bem-feita" foi cunhado por
} Eugene Scribe por volta de 1825, numa época em que a revolução francesa já consolidara seu caráter burguês conservador. Segundo Stephen Stanton (1957, p. 59), sua estrutura apresenta uma fórmula que segue sete elementos estruturais precisos e necessários:

[1] uma trama vivaz baseada num segredo que é escondido da maioria dos personagens (mas conhecido pelo público) até a cena do clímax na qual sua súbita revelação serve para expor um personagem fraudulento e restaurar o estado feliz do herói desafortunado com qual o público se identifica; [2] uma estrutura de ação e suspense que está sendo cada vez mais intensificada por entradas e saídas forçadas, cartas inesperadas, e outros mecanismos - uma estrutura que surge de uma exposição lenta e deliberada nas primeiras cenas; [3] um conflito prolongado entre o herói e seu antagonista, pontuado por uma série de altos e baixos na sina do herói; [4] o fim do conflito marcado por duas cenas agudamente contrastantes, conhecidas como peripécia e cena obrigatória, que apresentam os pontos mais baixos e altos, respectivamente, nas aventuras do herói e revelam o segredo escondido frente ao lado oposto; [5] um mau-entendimento fundamental, ou quiproquó, revelado para os espectadores mas encoberto para os participantes; [6] um desenlace lógico e plausível; e [7] a reprodução dessa macroestrutura em cada ato da peça. (Tradução nossa) ${ }^{2}$.

$\overline{2 \text { No original: "[1] }}$ a lively plot based on a secret which is withheld from most of the characters (but known to the audience)
E John Russell Taylor (2014, p. 12) aponta um entrecho semelhante, responsável pela estrutura das peças do aluno mais importante de Scribe, Victorien Sardou, mas frisa ainda que as peças de Scribe se pautaram não na

[...] construção de um drama enquanto totalidade, como Racine a teria compreendido, mas basicamente na distribuição espacial e temporal de efeitos de tal maneira que um público pode ser mantido num estado de expectativa do início ao fim. (Tradução nossa) ${ }^{3}$.

As descrições indicam que o objetivo artístico era criar uma peça cujo material e estrutura garantem um público atraído pelo apelo emocional sem que a forma fira demais o realismo do drama burguês.

Quando um texto teatral faz uso de boa parte dos elementos estruturais de uma peça bem-feita, mas de modo irônico, pois o que Ihe interessa é confrontar o público com sua própria consciência convencional, entre outras por meio da crítica dos chavões estruturais da peça bem-feita, essa peça passa a ser reconhecida como problem play, como os dramas de Ibsen e Shaw. O dispositivo construtivo da

until the climactic scene, where its sudden revelation, serves to expose a fraudulent character and restore to grace the unfortunate hero with whom the audience identifies itself; [2] a pattern of action and suspense, increasingly intensified by contrived entrances and exits, unexpected letters, and other devices-this pattern springing from much slow and deliberate exposition in the early scenes; [3] a sustained conflict between the hero and his adversary, punctuated by a series of ups and downs in the hero's fortunes; [4] the end of the conflict, marked by two sharply contrasted scenes, known as the peripeteia and the obligatory scene, which present the lowest and the highest points, respectively, in the hero's adventures and reveal the withheld secret to the opposing side; [5] a central misunderstanding or quiproquo, made obvious to the spectator but kept from the participants; [6] a logical and plausible denouement; and [7] the reproduction of this overall action pattern in each individual act of the play".

3 No original: "[...] overall construction of a drama such as Racine would have understood it, but at least the spacing and preparation of effects so that an audience should be kept expectant from beginning to end". 
peça bem-feita, por sua vez, convida seu leitor e público a identificar-se harmoniosamente tanto com o material social quanto com os recursos formais convencionais, ao invés de deliberadamente provocar nele uma reflexão sobre os princípios estruturantes seja da dramaturgia, seja do mundo social da ficção e da vida empírica, para indagar-se sobre as forças formadoras de seu mundo. É a exigência de um fim harmonizante que impõe uma "supremacia da técnica" e faz com que sua racionalidade específica não só "não poup[e] o texto da superficialidade, da falta de visão e da artificialidade" (Guinsburg et. al., 2006, p. 236), mas o imprima tais limitações.

A técnica visa organizar, como vimos, peripécias, situações surpreendentes e quid pro quo engraçados de tal maneira a configurar uma história emocionalmente cativante, sem que os adornos narrativos ferissem o caráter realista da história. Ou melhor, sua verossimilhança, e com isso seu grau de realismo, é tanto testada quanto respeitada por sua eficácia emocional específica. A ela devem servir os elementos estruturais fixados. Isso indica a função ideológica dessa dimensão afetiva e sensacionalista, cujo escapismo é camuflado pelos recursos realistas, mas revelado pelo excesso de peripécias.

Essa interação entre eficácia emocional e seu enquadramento num naturalismo realista é a base formal da finalidade moralista da peça bem-feita. Os procedimentos que encontramos - na técnica de criar constantemente expectativas para no final oferecer uma solução alegremente conservadora - revelam como função fundamental da peça bem-feita a formulação de uma quase transgressão na qual está inscrito obviamente um desejo por esse horizonte outro; uma insatisfação para com as regras estabelecidas da vida burguesa e do drama burguês tradicional, mas ao mesmo tempo um profundo medo ou uma má vontade de ultrapassar os limites formais e conteudísticos postos por esse mundo. Em outras palavras, a crítica mantém-se nos limites de um moralismo já posto, da mesma maneira como a visão transformadora não passa de um frisson excitante, mas em última instância sem consequências.

Como podemos, então, aplicar ao contexto contemporâneo brasileiro essa dialética de uma poética de escrita teatral representar ao mesmo tempo o resultado de uma época nova numa visão conservadora, ao usar seus impulsos críticos de uma maneira esvaziadora?

\section{Três breves estudos de caso}

\subsection{Vinícius Calderoni e sua trilogia placas tectônicas}

À primeira vista, a escrita de Vinícius Calderoni pouco tem a ver com a peça bem-feita nos moldes modernos. Aos textos falta uma estrutura narrativa linear causal, o que já sugere o deslocamento do conflito da trama ficcional para uma instância meta-teatral, ou melhor, compositiva, referente à estrutura do texto. Concomitantemente, a criação de personagens mal segue princípios de um realismo psicológico. De fato, a relação entre personagem e linguagem inverte a dinâmica de causa interna (psicológica) e efeito externo (a materialidade e retórica da linguagem). Dessa maneira, o personagem principal das peças é uma figura uma vez coletiva, uma vez anônima: a concretização de um discurso social na boca de um ator que nos apresenta um ser humano - sendo esse efeito de uma situação 
social e de sua discursividade típica. Tampouco encontramos um segredo e mal-entendido a cujo redor circula a narrativa, ou melhor, eles são tratados como a regra e não a exceção da comunicação humana. Consequentemente, o dénouement numa "cena a fazer" fica impossibilitado. Nenhuma figura ficcional fica surpresa ou aliviada com a confissão explícita de um conteúdo onipresente e já vivenciado na prática. Mas, da mesma maneira como o herói deixa de ser uma figura individual e se transforma em figura de linguagem social, podemos observar que os truques narrativos da peça bem-feita reaparecem como jogos de linguagem, oscilando entre fricções e harmonizações linguísticas, oferecendo uma continuidade não-causal entre as cenas por meio de um travelling de palavras idênticas por contextos distintos e, consequentemente, de um deslizamento constante do sentido dessas palavras e das cenas. Ou seja, a partir da percepção inicial de que o herói da dramaturgia contemporânea é a linguagem em sua construção social, podemos identificar funções parecidas às da poética narrativa (rocambolesca, oscilante, harmonizante e aliviador) em seu vai-e-vem de cenas mais ou menos realistas, mas ao mesmo tempo beirando a implausibilidade, cenas dramáticas emocionalmente cativantes e bem humoradas em seu flerte com o escândalo moral.

Desse ponto de vista, não surpreende a coexistência relativamente harmônica de um eclético, mas apurado feeling formal acerca das características estruturais e materiais do mundo atual, com um gesto retórico de esvaziar o tempo e a geografia contextual de sua trilogia e de esconder na estática de um bem-humorado requinte verbal a dinâmica intrínseca desse contexto histórico. Se as temáticas citadas pelo material linguístico apontam ex- periências sociais complexas e muito dolorosas em suas contradições, o tratamento retórico jocoso e lúdico esvazia as contradições e as transforma em paradoxos criados por truques linguísticos. Ao invés de criar, no plano da narrativa, uma "cena a fazer", fabrica-se no plano da linguagem um "clima a manter". Um clima que podemos caracterizar com a avaliação popular de que no mundo avesso a viver as consequências de suas contradições, os conflitos se tornam escândalos e as contradições acabam forçosamente "em pizza". Ou dito de maneira mais erudita, o que poderia ser uma paródia crítica do funcionamento social vira um pastiche de formas pré-moldadas. ${ }^{4}$ Esse esvaziamento de um conteúdo potencialmente doloroso (e inclusive da forma alegórica que possui alguma força analítica para falar do mundo atual) pelo tratamento excessivamente técnico da escrita, é atestado pelo amigo e colaborador do autor, Ricardo Gomes. Diz ele:

[O] que está dentro da cabeça de Vinícius Calderoni [...] são todas as banalidades anestesiantes, todo o entulho existencial, todos os escombros que fazemos daquilo que fizeram (fizemos) de nós. [...] Um exército de manequins refugiados. [...] Autômatos. Pessoas forçosamente conformadas com as perdas das próprias pernas. [...] Narradores tentando concatenar informações que não sabemos se constituem uma piada, uma denúncia, um sonho, uma reportagem sensacionalista ou um meme. Mas que, no fim das contas, deve ser só uma piada mesmo. Sem fim. (Calderoni, 2017c, p. 14).

Como se articulam essas "banalidades anestesiantes", esse "entulho existencial", para poder formar pouco mais que uma piada? Encontramos, entre outros recursos, o desen-

4 Sobre a diferenciação entre paródia e pastiche, ver Jameson (2002) e Eagleton (1995). 
caixe de réplicas e o deslocamento brusco do endereçado, o que produz ao mesmo tempo uma escrita fluida e desconexa, cheia de buracos (ou de micro-peripécias numa terminologia mais tradicional):

Paula: Eu quero encostar na sua pele macia, eu quero te beijar dos pés à cabeça.

Sergio: Relaxa aí, toma um uísque, assiste uma tv...Oi, mãe! E esse texto você já leu?

Julio: Um táxi. Um táxi vazio. Um táxi que transporta o amor da minha vida.

Lara: Um táxi logo depois de deixar o amor da minha vida em seu destino, voltando a ser um táxi vazio. Eu quero morder esses seus lábios carnudos até sair sangue.

Paula: Porque você não tira sua roupa? (Calderoni, 2017a, p. 19).

Percebe-se também a repetição da mesma palavra em cenas distintas o que serve para dar suavidade a uma transição que não possui um nexo causal e às vezes nem temático, sendo pouco mais que um truque (como a apresentação surpreendente de uma carta desconhecida na peça bem-feita tradicional) para oferecer uma diversão textual. Tematicamente falando, permite estabelecer uma oscilação de pontos de vista que não implicam consequências, apesar da onipresença sugerida pela técnica do travelling linguístico:

[Narrador não nomeado da cena 2, no final de uma longa reflexão e narração de mais que cinco páginas]: ...se você olhar bem, todos os vínculos que se tem na vida são sempre um pouco precários. Os fios que nos conectam às pessoas que amamos e às coisas que fazemos. É exatamente como um fio, e, como um fio, pode ser facilmente rompido. Não sei, tô sendo muito chato?

JANAìnA: Pros outros não sei, mas para mim, que já te ouvi falar disso umas duzentas vezes, um pouco. [ri e abraça PEDRO]

PEDRO: A gente já entregou o papel do estacionamento?

JANAIINA: Já, tava na minha bolsa, lembra? (Calderoni, 2017b, p. 30, grifos nossos).

Em nível daquilo que tradicionalmente é denominado de personagem, apreendemos sua transformação em discurso padronizado, seja esse discurso social ou afetivo (instâncias de enunciação denominadas de Amigo Cômico e Amigo Trágico (Calderoni, 2017c, p. 23) ou produzido por instâncias sem definição cuja fala remete diretamente aos meios de comunicação e seu estilo de notícia sensacionalista (Calderoni, 2017a, p. 20), ou um discurso alegórico com figuras intituladas Esperança, Ódio, Medo (Calderoni, 2017c, p. 43), ou figuras aparentemente individualizadas que alteram entre a posição de narrador e de interlocutor (Calderoni, 2017b, p. 52-56) ou figuras que expõem, junto com sua fala, o subtexto destoante (Calderoni, 2017c, p. 29-33).

O que atravessa esses exemplos como fio condutor comum é uma ausência de interioridade, tanto na comunicação intersubjetiva quanto na percepção intrasubjetiva, como se as figuras não fossem capazes de viver a partir de uma vontade própria. É o mundo, por meio de suas máscaras linguísticas em forma de discursos sociais, que os conduz e que dirige suas maneiras de relacionar-se e comportar-se.

Estamos perante uma relação humana de passividade ante forças externas - forças que se manifestam como leis de mercado, práticas de comunicação comercial e publicitária que atravessam o mundo e às quais os seres humanos se veem (ou acreditam) obrigados a sujeitar-se, transformando a si mesmos em efeitos dessas posições sociais ou libidinais: 
"Pessoas forçosamente conformadas com as perdas das próprias pernas."

Não é que essa atitude está também na raiz da forma específica da intriga da peça bem-feita? Uma intriga na qual incidentes surpreendentes, em geral pouco motivados pelas ações das figuras, levam os conflitos a um final feliz; uma felicidade que consiste em perceber que os conflitos foram nada mais que alguns mal-entendidos e que uma harmonia preestabelecida - a mão invisível que milagrosamente dirige as peripécias narrativas - se impõe também ao final da intriga de tal maneira que o destino premia invariavelmente o herói? Certamente, entre o século XIX e a atualidade, a descrença perante esse tipo de solução ficcional se agravou, talvez até virou um niilismo abundante em círculos intelectuais, mas a tentativa de vivenciar um prazer na dor da passividade (real ou acreditada) permeia ambos os estilos teatrais.

A descrição que o próprio Calderoni faz da estrutura de sua primeira peça nos remete à aglomeração de faits divers na peça bem-feita do século XIX. Escreve Calderoni:

Penso que Não nem nada é um grito coral polifônico, um concerto sinfônico camerístico de caos ordenado, um texto/espetáculo em plano-sequência historicamente situado entre as coisas que existiam antes de nós e as coisas que serão criadas depois que morrermos, num momento frágil do tempo que podemos chamar de 'este exato instante' - que nunca mais vai se repetir e é completamente insuficiente. (2017a, p. 9).

Aqui encontramos condensados uma visão da história tanto individual quanto social sem especificidades e sem constantes, a não ser aquela importantíssima de ter seu olhar preso no plano sequência de instantes desconexos e privados de plenitude. O conteúdo perceptível nesse instante contínuo muda incessantemente, mas não sua qualidade de insuficiência e de efemeridade absoluta.

Calderoni percebe que essa estrutura de sua escritura está ligada ao espírito de nosso tempo. Na introdução a sua última peça, Chorume, ele nos diz (2017c, p. 7) que reagiu com esse texto a uma provocação que dialogava com as outras peças da trilogia: a de escrever

\begin{abstract}
um espetáculo que se propusesse a encenar coisas tão exóticas quanto um manifesto político, manuais de instalação de eletrodomésticos, bulas de remédio, placas de trânsito, entre outras manifestações [...] ficou claro, naquele instante, que essa premissa se relacionava em muitos aspectos com questões presentes na dramaturgia de Não nem nada e com temáticas que estavam começando a despontar em Arrã.
\end{abstract}

É patente que os textos de Calderoni se apresentam como um sintoma da globalização neoliberal com suas relações sociais aparentemente líquidas. E revelam o problema que surge quando os artistas querem fundar sua autonomia artística num gesto autorreferencial que se nega a marcar no interior de seus textos como dialogam concretamente com seu contexto social. Para Calderoni e Gomes, "as coisas vão acontecendo. E saber onde elas começaram provavelmente não vai mudar seus desfechos" (Calderoni, 2017c, p. 14). Essa atitude fatalista é, a meu ver, estruturalmente correspondente com as estratégias dos marqueteiros neoliberais do sistema financeiro atual de apresentar decisões políticas como medida obrigatória sem alternativa, exigida pelo funcionamento da realidade supostamente única que se chama economia neoliberal. Elas são também responsáveis pelo fato de que aquilo "que era ainda construção [...] já é ruína" (Cal- 
deroni, 2017c, p. 9).

Entretanto, na música Fora da ordem de Caetano Veloso, que a frase cita, essa constatação se refere ao contexto explícito de uma escola pública que virou boca dos adolescentes armados pertencentes ao narcotráfico. E Caetano remete a busca por prazer o tempo todo às forças que impelem os seres humanos a refugiar-se num mundo privado cujo prazer, portanto, é moldado pelas forças dessa nova ordem. Nos textos de Calderoni essa relação fica no máximo implícita e pressuposta, sem ser tematizada. Antes, ela é esvaziada de sua dimensão social concreta a tal ponto de expressar uma operacionalidade abstrata a qual o ser humano pode assistir e dentro da qual ele pode agir, sendo um motor automatizado de sua produção. A questão que se coloca aqui é: até que ponto a dramaturgia de Calderoni apenas contribui para formar um vaudeville em ruínas, mas mesmo assim quase infantilizante, ou consegue constituir uma comédia social paródica que expusesse a estrutura da dinâmica social em curso? Até que ponto é uma peça bem-feita ou um problem play?

\subsection{Pensamento politizado em uma moldu-}

\section{ra dramática ensimesmada: Jô Bilac}

Diante dessa proposta de procurar novos avatares da peça bem-feita, em conjunção com um ideário teatral contemporâneo, tomemos como exemplo duas peças do dramaturgo carioca Jô Bilac, que abordam questões relacionadas a uma estrutura que parece estar adquirindo contornos na literatura dramática brasileira contemporânea: Conselho de classe, escrita para a comemoração dos 25 anos da Companhia dos Atores (2013), e Alguém acaba de morrer lá fora (encenada em 2011). Nos dois casos, há particularidades estrutu- rais que salvaguardam as especificidades de cada peça, e as compreendemos aqui como projetos políticos enquadrados em formatos estruturais conflitantes. Isso, a priori, nos levaria a crer em uma potência de crise, de antinomia entre forma e conteúdo. No entanto, o que queremos destacar é que, em face de uma composição dramática, o discurso politizado recai num lugar de pouca exploração. Nesse sentido, o que marca em particular esses dois textos de Jô Bilac não é, tal como em Vinícius Calderoni, a despolitização da peça em uma arquitetura bem estruturada, mas o enfraquecimento da perspectiva crítica que é, a princípio, o leitmotiv das peças, diante da forma adotada. Ou seja, em ambas há um processo relativamente próximo, que é um discurso pretensa e potencialmente politizado que não é absorvido por completo pela estrutura e, em virtude disso ou em conjunção a isso, acaba não tendo maior aprofundamento no encaminhamento dramático.

Tanto em Conselho de classe quanto em Alguém acaba de morrer lá fora há a intenção do discurso crítico à sociedade anestesiada e imobilizada diante das condições em que se encontram suas personagens. O que vemos, no entanto, na articulação desse discurso a uma escolha estética, é a reafirmação de alguns lugares comuns, escapando para a banalidade das situações e arranjando saídas fáceis e diluídas para o problema proposto.

Em Conselho de classe, durante uma reunião de conselho de classe de uma escola estadual, quatro professoras discutem o imbróglio que coloca a situação da escola num lugar de conflito: os alunos se rebelaram contra as ordens da diretora, o que provocou um acidente seguido de um surto psíquico dela, e seu consequente afastamento. Surge, então, 
um jovem diretor substituto que tenta conciliar os embates que surgem entre as professoras. A narrativa é baseada fundamentalmente nos conflitos individuais e joga com a banalidade das situações, ocasionando numa estrutura ensimesmada, que não transborda os limites do drama.

O que se nota é uma tentativa de colocar em choque as opiniões opostas e contraditórias do corpo docente, o que de fato ocorre, embora $\mathrm{o}$ argumento em alguns momentos reproduza os velhos chavões que pautam a discussão sobre o ensino público, pouco se distanciando da reafirmação do que se vê nos meios midiáticos. Evidente que há uma disposição irônica no texto em relação à opinião sedimentada sobre professores, alunos e escola. Mas a expansão de sua veia crítica e do debate esbarra, justamente, na proposição formal escolhida, fechada e interpessoal.

Talvez pudéssemos relacionar, de alguma forma, esses temas do cotidiano que emergem na narrativa da peça àquilo que Sarrazac (2017) chama de infradramático: a representação de personagens muito comuns, em que "nada acontece", sem grandes catástrofes. No entanto, como o crítico francês observa, o "infradramático não mora somente na falta da estatura das personagens, dos acontecimentos e outros microconflitos; ele liga-se à subjetivação e, portanto, à relativização que marca todos esses microacontecimentos e microconflitos. Em outros termos, muitas vezes é com um teatro íntimo e de conflitos intrassubjetivos, intrapsíquicos que estamos lidando" (Sarrazac, 2017, p. 54). É então que reconhecemos as limitações dessa dramaturgia, na medida em que seu formado fechado, dramático, não captura o íntimo do íntimo para referir-se ao universal. Ela, no entanto, permanece circuns- crita às situações convencionais do jogo intersubjetivo, articulando em si os lugares comuns sociais sobre educação, escola pública, professores etc.

Há, ao longo da exploração da problemática escolar, uma preocupação legítima de se aproximar desse conteúdo crítico em relação às condições cotidianas de uma educação que é costumeiramente tratada como "perfumaria" na vida política brasileira, da mesma forma como a profissão é considerada inferior e menos interessante socialmente. E esse discurso está presente na peça, levantando os paradoxos vivenciados, as condições exaustivas e as ingenuidades que acompanham a formação do educador no Brasil. No entanto, não seria bastante curioso que tal discurso esteja diluído entre as opiniões diversas, quase obnubilado pela forma convencional que assume a peça, dialógica e bem estruturada? Nesse sentido, o que pode parecer aqui é uma aproximação demasiada com esse lugar comum educacional sem distanciar-se de forma apropriada dele para enfim discuti-lo com a devida atenção.

$O$ que, nesse sentido, alinha tal peça a uma certa ideia de peça bem-feita contemporânea seria seu uso bem articulado da estrutura, marcadamente dando conta de uma situação contraditória e crítica por si só na formulação algo fechada do drama, sedimentando assim o conteúdo na forma. Isso, em si, não é um problema para o teatro contemporâneo, que tem como caráter fundamental as possibilidades artísticas variadas. O que vemos, nos parece, é a reafirmação, pela articulação do conteúdo à forma, de um discurso hegemônico que não encontra resistência: depois de uma longa tarde de discussão, o jovem diretor substituto abre pacificamente sua cerveja com a professora Célia, e ambos vão para suas casas 
acomodados com a condição. Há um apaziguamento do debate posto, pela simples solução narrativa de desfecho da fábula. Assim, acompanhamos a problemática em uma estrutura bastante fechada, dialógica e absoluta, seguindo os termos szondianos de análise.

Alguém acaba de morrer lá fora é, segundo seu dramaturgo, uma insurgência "contra a burguesia e sua alienação desrespeitosa com o outro", e carrega consigo "os discursos repetitivos, o senso comum, a opinião rasa a respeito das coisas, a indiferença, o abismo" (2012, p. 6). De fato, estamos diante de uma situação de inércia, em que as personagens em cena nada fazem e, de formas diferentes, encaram a morte em sua violência imediata. Ao propor contar quatro versões diferentes de reações diante de um atropelamento - quatro possibilidades de enfrentamento da morte -, a preocupação da dramaturgia recai muito mais sobre a forma da narrativa e sua solução do que necessariamente sobre aquela alienação burguesa prevista na apresentação da peça. Novamente, assim como em Conselho de classe, vemos diante de nós uma profusão de lugares comuns - narrativos e ideológicos - que nos fazem perder a dimensão exata do que a peça almeja tematicamente.

Em um bar, três clientes - Cláudio, Laura e Marcela - esperam por alguém com quem marcaram um encontro naquele local, enquanto fazem pedidos a um garçom mal-humorado. Depois de uma breve discussão sobre a condição deles e um acontecimento - o barulho de um atropelamento na rua -, a história é repassada com variações conforme visões potencialmente diferentes. Em todos os casos, desloca-se a perspectiva e se reconfiguram os caminhos e os impactos da morte em cada personagem, desarticulando o eixo cen- tral da narrativa. Enquanto estrutura dramatúrgica, portanto, a peça é potente em sua relação entre os dispositivos de que lança mão, estabelecendo uma história que se desdobra em várias e desestruturando o espectador/leitor diante do que vê. Cheia de reviravoltas e efeitos de impacto, o texto deixa escapar, com isso, seu discurso oficial, na medida em que a crítica social e politizada se desarticula diante da descontinuidade narrativa. Queremos notar, diante desse jogo dramático que se estilhaça diante do espectador, que o discurso politizado e potencialmente crítico sobre a dita burguesia pós-moderna fica escorregadio diante das convenções dramáticas assumidas.

"Ouve-se uma freada brusca de um carro do lado de fora do café. Instintivamente, todos olham para a porta de vaivém. Vozerio do lado de fora. Expectativa" (Bilac, 2012, p. 29). A partir de uma cena inicial, em que as personagens são apresentadas e também estão expostos os seus mistérios particulares (cada um marcou um encontro para aquele horário), e um breve enfrentamento com o garçom Dodô, essa rubrica marca o ponto de convergência das cenas seguintes. A continuidade é circular, em diferentes versões sobre o que poderia vir após o atropelamento: pressupõe-se, em cena, o que seria a reação de cada um se o atropelado fosse a pessoa com quem tivesse marcado o encontro. Então, são projetadas as reações de Cláudio, Laura e Marcela. Desmembra-se, assim, a narrativa em braços de possibilidades, marcando a imprecisão fabular. A estrutura, em si, é o que ganha destaque nessa dramaturgia, atraindo a atenção, divertindo e marcando seu objetivo. Nesse sentido, o que vemos, a exemplo do que ocorre em Conselho de classe, é um esvaziamento do discurso pretendido (declaradamente anti-burguês pelo autor) em virtude 
da atenção dedicada à forma de narrar.

Se há um pressuposto sobre a experiência ou o impacto de cada um diante da morte, ou mesmo uma necessidade de abordar a futilidade e o vazio da vida burguesa, ele fica enfraquecido pela ordem estrutural, incitada a fim de provocar certo impacto no público pela imprecisão de que lança mão. Ainda na cena inicial, ocorre um breve embate entre o garçom e os clientes por causa de troco: "Cláudio: ... [indo até o balcão, puxa o dinheiro] Pela água./ Dodô: Não tem menor? [...] Dodô: [encara, impaciente] Tô sem troco... Alguém troca?" (Bilac, 2012, p. 27). Diante da negativa dos outros clientes, instaura-se uma discussão entre eles, com frases como "Marcela: Você deveria se esforçar mais pra agradar sua clientela!" ou "Dodô: E a senhora é uma burguesa metida a besta!/ Dodô: Todos vocês! Escrotos! Chorando de barriga cheia!" (Idem, ibidem).

A cena não vai muito além disso e dá lugar justamente para as proposições formais. Logo após o "bate-boca generalizado", o personagem Cláudio aparta a briga com frases como "E eu tenho certeza de que o Dodô se esforçará um pouco mais para conseguir o meu troco, não é, Dodô?" (Idem, p. 28). A cena se encerra sem ampliar o debate, e a peça segue sua proposta de desenvolver as várias possíveis continuações da história, partindo sempre do atropelamento. Assim, aquilo que se apresenta por sua potencialidade crítica acaba sendo submergida pela estrutura em jogo. $O$ que se vê, com isso, é a repetição dos lugares-comuns que mais reafirmam os estereótipos do que os problematizam.

Nesse sentido, diante dessas duas peças de estruturas aparentemente diversas, a relação com uma pretensa peça bem-feita contemporânea pode ser alinhada a um senso amplo do político. A peça bem-feita do século XIX estava, direta ou indiretamente, ligada a um pensamento de classe, em vista do crescimento da burguesia e a ânsia que se tinha de criar ou projetar um modelo para o público. Buscava-se, assim, um efeito moral, adequado à classe que representa. Em vista disso, dá-se privilégio à formulação verossímil, de forma que o público se reconheça no modelo projetado em cena, efetivando o molde do público conforme as normas morais tidas à época como vigentes (v. Faria, 2006).

É nesse sentido que reconhecemos o funcionamento da dramaturgia de Jô Bilac, que abarca e reproduz um discurso moral de um nicho social, mas sem expandir o debate. $\mathrm{Ou}$ seja, ao se apropriar de uma estrutura fechada, ela não dá espaço às discussões politizadas que o dramaturgo almeja e coloca em estado de potência. Ao contrário, o simples apaziguamento das questões praticamente reforça o senso comum, de forma que um público particular se reconheça no discurso habitual. Há, enfim, uma reprodução dos lugares comuns vistos, aproximando-se assim desse efeito realista do comum, e marcando as escolhas dramáticas de verossimilhança.

\subsection{João Sanches e a comédia Entre nós:} peça bem-feita ou problem play?

As peças de João Sanches são exemplos de dramaturgia contemporânea encenada e publicada no Nordeste, particularmente em Salvador, na Bahia. O premiado texto Entre nós: uma comédia sobre diversidade (Sanches, 2015) apresenta dois atores que criam uma peça sobre diversidade sexual no momento da apresentação. Para isso, discutem, narram e encenam a fábula simultaneamente. A partir dessa estrutura metadramática, as per- 
sonagens-atores vão inventando outras personagens e compondo uma intriga cujo desfecho o leitor/espectador terá que arbitrar. As personagens-atores interpretam a história de Rodrigo e Fabinho, dois jovens estudantes do ensino médio que, apesar de envolvidos afetivamente, não conseguem sequer se beijar pela primeira vez. Com abordagens antagônicas sobre o tema diversidade sexual, as personagens-atores discutem sobre as características e atitudes de Rodrigo e Fabinho, sobre o desenvolvimento da intriga e, finalmente, sobre o desfecho da trama. Depois que os adolescentes superam uma série de situações que impedem o beijo dos dois, o casal ainda enfrenta um último empecilho: a divergência dos atores sobre se eles devem ficar ou não juntos no final e se a cena deverá ter beijo.

ATOR1 - Não, na verdade, eu acho que não deveria ter o beijo.

ATOR2- Uma história de amor sem beijo??

ATOR1- Exatamente. Muito menos óbvio. E bem contemporâneo.

ATOR2 - Ah, não...

ATOR1- Hoje em dia, o comum é o relacionamento não dar certo.

ATOR2- Mas nesse caso o relacionamento nem começou.

ATOR1- Bem contemporâneo.

ATOR2- Eu acho muito pessimista. MeIhor ter o beijo.

ATOR1- Muito melhor deixar a coisa em aberto.

ATOR2- Esse lance de deixar o casal gay sem beijo é muito novela.

ATOR1- Esse lance de ter beijo romântico no fim também.

ATOR2- Ok. Então a platéia decide. Super contemporâneo.

ATOR1-O público decidir o fim da história é coisa de programa de TV dos anos 90.

ATOR2- Gente, a verdade é que o meu colega aqui é heterossexual e está resistindo em me beijar. Pronto. Falei.

ATOR1- Nada a ver! De jeito nenhum! Eu só acho que não tem que rolar beijo porque é muito menos óbvio. (Sanches, 2015, p. 125-127).
Diante da situação, o leitor/espectador é convidado a decidir se o casal de personagens pode, enfim, se relacionar e realizar o beijo impedido durante todo o espetáculo, ou se a peça deve terminar com uma música que "deixa o fim em aberto". O texto sugere que plateia vote e oferece as duas opções de desfecho, mas é evidente o intuito de que a plateia escolha o final que autoriza o beijo e a relação.

Interessante notar que, com um beijo final, os dois planos desse metadrama (plano das personagens-atores e das personagens que eles interpretam) se fundem. Se pensarmos ainda que o devir cênico do texto aponta para a realização performativa do beijo por dois homens, ao vivo, na presença de uma plateia que escolheu esse acontecimento por meio de uma votação, podemos concluir que a peça propõe (e sua encenação proporciona de fato) um acontecimento (micro)político imediato, diretamente ligado ao tema e a todos presentes em cada apresentação.

Formulada por Sarrazac (2012), a noção de devir cênico se refere à força e às virtualidades cênicas de uma obra, ou seja, "pelo que num texto - que pode ser não dramático - solicita o palco e, numa certa medida, reinventa-o" (Sarrazac, 2012, p. 66). No caso de Entre nós, o devir cênico da dramaturgia extrapola o universo ficcional da intriga, ou da situação metadramática da peça, e provoca os leitores/ espectadores no sentido da realização de uma ação afirmativa direta, via dramaturgia e encenação.

Se considerarmos ainda a noção de desvio (Sarrazac, 2012), podemos identificar muitos procedimentos dramatúrgicos que se desviam de modelos tradicionais ou majoritários: recursos metalínguisticos, narrações, questionamentos, variações de tempo e espaço, frag- 
mentações da fábula e apelo à intervenção direta do leitor/espectador, com dois desfechos diferentes para a intriga.

A dramaturgia de Entre nós, portanto, adere a dispositivos de enunciação bastante recorrentes nas dramaturgias moderna e contemporânea: "O questionamento, sempre essa tendência filosófica, que encontramos em Pirandello, Brecht, Strindberg ou Beckett, invade a 'ficcionalização' e contribui para redistribuir o material em função do fabulador. Poder-se-ia dizer, num sentido quase judiciário, que a fábula é processada" (Sarrazac, 2017, p. 10).

No entanto, é preciso reconhecer que não há nada de novo na utilização desses desvios, uma vez que eles sempre foram recorrentes nas dramaturgias de cunho épico e há muito tempo foram incorporados por construções contemporâneas que não teriam, em princípio, intenções de produzir uma dramaturgia efetivamente crítica. No caso de Entre nós, a intenção crítica é explícita mas, se por um lado a dramaturgia realiza desvios de tendência épica, por outro lado, a peça também apresenta grande parte dos aspectos que neste artigo são associados à peça bem-feita contemporânea como, por exemplo, a busca por eficácia emocional, garantida pela identificação do leitor/espectador com as personagens e com uma intriga que o mantém em suspense, que o entretém com peripécias, reconhecimentos e situações surpreendentes. Essa estrutura configura um enredo e uma teatralidade que cativa emocionalmente e, com isso, também busca alcançar um efeito moralizante. Esses aspectos são evidentes em Entre nós, pois o texto apresenta tanto o casal enamorado quanto a dupla de personagens-atores que o interpreta de maneira realista e individualizada, com o objetivo de criar identificação e empatia com o leitor/espectador. As outras personagens (heterossexuais) da trama, no entanto, são apresentadas de um modo mais caricatural (com efeitos de estranhamento que destacam e criticam atitudes preconceituosas naturalizadas em nosso cotidiano).

Cheia de reviravoltadas e situações complicadas, a intriga de Entre nós, embora apresente muitos desvios autorreflexivos, reúne quase todos procedimentos da peça bem-feita, inclusive a tradicional "cena a fazer", a cena "obrigatória" na qual os antagonistas se enfrentam de maneira definitiva.

Nesse sentido, seria Entre nós uma peça bem-feita contemporânea? Seria a intriga e o desfecho feliz da peça (o beijo e afirmação do afeto dos dois homens) uma solução alegremente conservadora? Ou seria a adoção de princípios da peça bem-feita (particularmente a eficácia emocional e o intuito moralizante) uma apropriação irônica da dramaturgia de Entre nós? Seriam esses procedimentos convencionais utilizados para, justamente com sua eficácia, demonstrar que as convenções estabelecidas não incluem a todos? Seria Entre nós "a problem play"? Ou, pelo contrário, com sua estrutura "bem-feita" a peça apenas reafirma os valores burgueses pós-modernos, apesar de realizar uma crítica pontual? Reclamar o reconhecimento da homoafetividade pela sociedade atual, nesses termos, significa afirmar seu atual sistema de funcionamento?

\section{Breve conclusão}

Se os exemplos dramatúrgicos apresentados e discutidos neste artigo, sobretudo os primeiros dois, podem ser, sob diferentes abordagens, considerados novos avatares da 
peça bem-feita, naquilo que ela tem de conservadora, então talvez uma pergunta ainda mais produtiva deva ser feita: que dramaturgias contemporâneas no Brasil podem ser consideradas efetivamente críticas e transgressoras? Em que medida uma peça contemporânea consegue sustentar um discurso crítico a uma forma articulada e propositiva? Compreendemos, diante de certo espectro contemporâneo, que a saída que "acaba em pizza" apazigua e abandona as contradições e fricções necessárias para o pensamento crítico, deixando-se tomar pelo simples efeito de cena e que não sustenta a eficácia também em seu conteúdo. Entendemos que, para este fim, a peça precisará incorporar não apenas um material que tenciona dolorosamente a realidade empírica, mas também um acabamento formal que impossibilite que o teor do material possa ser assimilado ao status quo sem que esse passe por uma transformação ou um deslocamento estrutural decisivo de suas forças formadoras.

Referências

BILAC, Jô. Alguém acaba de morrer lá fora. Rio de Janeiro, Cobogó, 2012.

BILAC, Jô. Conselho de classe. 2. ed. Rio de Janeiro, Cobogó, 2016.

CALDERONI, Vinícius. Não nem nada. Rio de Janeiro: Cobogó, 2017a.

CALDERONI, Vinicius. Arrã. Rio de Janeiro: Cobogó, 2017b.

CALDERONI, Vinícius. Chorume. Rio de Janeiro: Cobogó, 2017c.
CARDWELL, Douglas. The well-made play of Eugene Scribe. The French Review. vol. 56, n. 6. May, 1983. pp. 876-884.

EAGLETON, Terry. "Capitalismo, Modernismo e Pós-Modernismo". In: Crítica Marxista. São Paulo: Brasiliense, v.1, n.2, 1995. pp. 53-68.

FARIA, João Roberto. Teatro e compromisso social. In: Antologia do teatro realista. São Paulo, Martins Fontes, 2006.

GUINSBURG, Jacó; FARIA, João Roberto; LIMA, Mariângela Alves de (Orgs.). Dicionário do teatro brasileiro: temas, formas e conceitos. São Paulo: Perspectiva, 2006.

JAMESON, Fredric. Pós-modernismo: a lógica cultural do capitalismo tardio. São Paulo: Ática, 2002.

SANCHES, João. Entre nós: uma comédia sobre diversidade. Salvador: EDUFBA, 2015.

SARRAZAC, Jean-Pierre. O futuro do drama. Porto: Campo das Letras, 2002.

SARRAZAC, Jean-Pierre (org.). Léxico do drama moderno e contemporâneo. São Paulo: Cosac Naify, 2012.

SARRAZAC, Jean-Pierre. Poética do drama moderno: de Ibsen a Koltés. São Paulo: Perspectiva, 2017.

STANTON, Stephen. Scribe's "Bertrand Et Raton": a well-made play. In: The Tulane Drama Review. vol. 2, n. 1. Nov. 1957. pp. 58-70. 
TAYLOR, John Russel. The rise and fall of the well-made play. London \& New York: Routledge, 2014. (Originalmente publicado em 1967 por Methuen \& Co. Ltd.)

VELOSO, Caetano. "Fora da Ordem" in: Circuladô. Gravadora: Elektra, 1991

Recebido: 04/12/2018

Aprovado: 11/01/2018 